WIELKIE TEMATY KULTURY W LITERATURACH SŁOWIAŃSKICH

Slavica Wratislaviensia CLXVIII • Wrocław 2019•AUWr No 3875

DOI: 10.19195/0137-1150.168.37

Data przesłania artykułu: 3.09 .2017

Data akceptacji artykułu: 30.11.2017

VLADIMIR VUKOMANOVIĆ RASTEGORAC

Универзитет у Београду, Serbia

\title{
Обликовање говора о смрти \\ на почецима српске поезије за децу и младе
}

Однос према теми смрти у дијалогу с децом је амбивалентан. Наставници осећају нелагодност кад о њој треба започети разговор у школи ${ }^{1}$, издавачи дечјих књига такав разговор недовољно подстичу ${ }^{2}$; истраживања, с друге стране, показују да и родитељи и наставници сматрају како је разговор на тему смрти са децом потребан ${ }^{3}$, а одрасли доста прецизно процењују да се концепти смрти јављају у раном детињству, што показује њихову свест о дечјем поимању умирања 4 .

Премда се на први поглед може чинити саморазумљивим, табу ћутања о смрти у друштву, па и пред децом, има идеолошке корене. Његов узрок Филип Аријес види у „обавези” да се допринесе колективној срећи: „показујући неке знаке туге, човек греши против среће, доводи је у питање, а друштво на тај начин ризикује да изгуби смисао постојања"5. Колико ћутање о смрти у школи може да буде идеолошки обојено постаје пак јасно кад се присетимо тезе Луја Алтисера о школи као државном идеолошком апарату који има задатак да репродукује производне (верујемо, и шире друштвене) односе ${ }^{6}$.

${ }^{1}$ V. Talwar, Talking to Children about Death in Educational Settings, [y:] Children's Understanding of Death, прир. V. Talwar et al., Cambridge 2011, с. 102, 104.

${ }^{2}$ I. T. Gutiérrez et al., Affective Dimensions of Death: Childrens Books, Questions, and Understandings, „Monographs of the Society for Research in Child Development” 2014, c. 1, 60.

${ }^{3}$ V. Talwar, Talking to..., c. 103.

${ }^{4}$ Уп. J. В. Ellis, J. E. Stump, Parents' Perceptions of Their Children's Death Concept, „Death Studies", XXIV, 2000, c. 68-69; M. W. Speece, S. B. Brent, Children's Understanding of Death: A Review of Three Components of a Death Concept, „Child Development” 1984, c. 5, 1683-1684.

${ }^{5}$ F. Arijes, Eseji o istoriji smrti na Zapadu, prev. Z. Banjac, Beograd 1989, c. 72.

${ }^{6}$ L. Altiser, Ideologija i državni ideološki aparati, prev. A. Filipović, Loznica 2009, c. 43-47. 
Један од начина да се са децом поведе разговор о смрти може бити разговор о поезији која овај феномен тематизује. Да би се до тога дошло, ваља најпре истражити репрезентације смрти и промене тих репрезентација. Систематичније проматрање тематизације смрти у српској поезији за децу досад није спроведено, па смо за циљ овог рада изабрали да сагледамо њено место на изворишту српске поезије за децу - унутар предзмајевског периода, који се и са̂м до данашњег дана налази на маргинама истраживања књижевних критичара и антологичара дечјег песништва ${ }^{7}$; та би слика потом могла да постане референтна тачка за даља истраживања представа о смрти у дечјој поезији. Отуда ће у овом раду бити анализиран дискурс о смрти у првим ауторским песмама које су експлицитно намењене деци и младима ${ }^{8}$, а које су настале из пера двојице плоднијих предзмајевских песника за децу и младе: Јована Сундечића и Ђорђа Рајковића.

Историја смрти у српској поезији за децу почиње са појавом прве оригиналне збирке намењене најмлађој публици. Јован Сундечић (1825-1900), свештеник по позиву, штампао је 1856. године збирку Низъ драгоиъьнгъ бисера, у којој тематизација смрти заузима значајно место - њена представа је, иако хомогена, доста комплексна.

Спочетка ваља рећи да је идентитет умирућег субјекта унутар збирке у различитој мери конкретизован. Присутан је, наиме, говор о смрти као догађају који не заобилази никога, као нпр. у песми На освету, која евоцира слику Страшног суда: „Праштаймо, єръ ће стати / Предъ Судца єдночъ свакій”9. Када се говори о универзалности важења смрти, њен узрок се по правилу не експлицира, смрт се не конкретизује ни просторно ни временски, а емоције које производи било у ономе који умире, било у онима који су у контакту са умирућим, у другом су плану. Ако се о њима говори, онда је то изостанак страха јер се смрт прихвата као нужност сваког живота ${ }^{10}$ или се ка њој иде са неком врстом предусретљивости у вери да после тегоб-

7 Уп. историјске прегледе у којима се овом периоду посвећује нимало или мало пажње: С. Ж. Марковић, Записи о књижевности за деиу, Београд 1973; Н. Вуковић, Увод у књижевност за дјеиу и омладину, Подгорица 1996; Д. Јекнић, Српска књижевност за деиу 1: историјски преглед, Београд 1998. Слично је и у најзначајнијим антологијама дечјег песништва: Дечја поезија српска, прир. Б. Ћосић, Нови Сад - Београд 1965; Антологија српске поезије за деиу, прир. Д. Радовић, Београд 1984. Једино озбиљно бављење овим периодом може се приписати Зорани Опачић: Антологија српске поезије за деиу предзмајевског перио$\partial а$, прир. 3. Опачић, <http://www.antologijasrpskeknjizevnosti.rs/ASK_SR_AzbucnikDela.aspx> [приступљено: 1.08.2017].

8 То овде ваља нагласити јер се потешкоће у вези с прецизнијим одређењем предзмајевског периода не тичу само установљавања временских граница, већ и критеријума којим би се јасно омеђила поезија за децу од онога што у дефинисаном временском одсечку поезија за децу није. Да бисмо избегли учитавања, у овом раду смо разматрали само оне песме које су објављене унутар дела експлицитно намењених деци и младима.

9 І. Сундечићъ, Низ драгоиъног бисера, У Задру 1856, с. 67.

10 „Нужда учи великимъ стварима [...] / Збогъ нъ страве неимаде смрть”. Ibidem, с. 71. 
ног постојања на земљи долази лепша, рајска егзистенција ${ }^{11}$. Говор о универзалности смрти подразумева да је она само прелазак у друкчији начин постојања. Њему пак претходи Божји суд за учињена дела у земаљском животу, на којем се прижељкује позитиван одговор („сладкій судъ”12). Рај се описује као нова отаџбина ${ }^{13}$ или се именује литургијском синтагмом царство божје или небесно царство ${ }^{14}$, а виђен је као „вђчно жиће блаженогъ свђта / Гдъ сваке сласти прольће цвьта”15, „Гдђ-но насъ тека / Само блаженство / За вавђкъ чека"16. Постојање загробног живота у великој мери одређује онда и смисао умирања, а тиме и живота, најконцизније исказаног у дистиху с краја Сундечићеве збирке: „Некъ ти буде средство животъ овый, / Да получишъ како треба новый”"17. Наративи о смрти тако добијају јак моралистички призвук, будући да се онострани живот мора заслужити врлином на земљи.

Моралистичког тона нису ослобођене ни оне песме у којима су умирући субјекти религијске фигуре и фигуре са друштвене маргине. У вези с првим, у Низу је тематизована Христова смрт, а само посредно и смрт Светог Саве (путем говора о његовом загробном постојању). У говорењу о узроцима Христове смрти упошљава се религијски правоверно тумачење његовог страдања као саможртвовања које има за циљ спасење људског рода, а о њој се говори са временске координате која означава празник ускрсења ${ }^{18}$. Разуме се да Христова фигура у великој мери одређује и визију загробног живота: реч је, дакако, о рају, у којем обитавају анђели, који се у одређеним приликама спуштају и на земљу међу људе да их чувају или с њима, примерице, прославе Христово ускрсење. О тренуцима смрти Светог Саве се, као што рекосмо, не говори, али се говори о томе да он постоји и после своје смрти, с десне стране Бога и да се тамо моли за српски род, чиме се осликава један део постморталног простора ${ }^{19}$.

11 „Хрістіянству кои сльди [...] / Тай већь окомъ ума пази, - / То блаженство обетано: / Па и у гробъ радо слази." Ibidem, c. 23.

12 Ibidem, c. 28.

13 Ibidem, c. 23.

14 Ibidem, c. 75.

15 Ibidem, c. 45.

${ }^{16}$ Ibidem, c. 75.

17 Ibidem, c. 91.

18 Смисао веровања у Христово васкрсење, које је умногоме и смисао његовог тематизовања унутар Сундечићеве поезије, може се повезати са речима Е. Морена: „Ако људи буду опонашали бога који умире, ако његово страдање буду доживљавали као своје сопствено, ако му се буду поверавали у току тајанствених свечаних обреда у којима се драма његовог страдања и васкрсења представља и доживљава, онда ће их после смрти чекати вечна младост, преображено тело које никада неће остарети ни умрети, права бесмртност”. E. Moren, Čovek i smrt, prev. B. Jelić, Beograd 1981, c. 245.

19 Често помињање смрти у хришћанском контексту може се повезати и с тим што је исповедање православне вере један од темеља српског националног идентитета у времену 
Тематизовање сиромаштва једна је од великих преокупација предзмајевских песника, која вероватно има подстицај у друштвеној стварности онога доба, а која је и овде добила израз. У песмама Одлаганъ милостинъ и Награда дъла' милости тъллесне већ у наслову постаје јасно на коју се особину младог читаоца апелује - било да је реч о саосећању које чини да се ономе кога сваког трена може да уграби глад помогне, било да се у смрти помилује тако што ће сиромаха, ако премине, без наплате часно сахранити ${ }^{20}$. Ангажман је најексплицитније остварен у песми Гробъ, једној од ретких песама која је просторно локализована - разуме се, реч је о гробљу, које је једно од повлашћених места у говорењу о смрти и које ће то остати и касније у српској поезији за децу. Лирско ја доводи свог младог саговорника до гробова богаташа и сиромаха, које именује „стаништима” ${ }^{2}$. Цела песма је заснована на контрастирању њиховог овоземаљског трајања и онога што је од њега остало. Иако би се, ако ни због чега другог, а оно због универзалности осећања грозе коју леш производи ${ }^{22}$, очекивало да се слика телесног распадања заобиђе у поезији за децу, њу ће већ Сундечић донети у својој збирци:

Кажи ми сада / Разлике єли, / Коя иьи овде / Лучи и дъли?... // Нъсу ли црви / И гує ине

/ Развукли оба / Єднако сыне!?... // Текъ имъ іошъ кости / Голе ту стоє / Али вай! какве / Различне боє: // Оногъ су црне, / Трулежъ ій мрви; / Разкошно єръ є / Живіо првый; / А овогъ другогъ / Ка' злато исто / Жуте се; єрбо / Живляше чисто. ${ }^{23}$

Контраст у приказу богаташа и сиромаха задржава се и после живота, а разуме се да оваква слика смрти подстиче друкчије емоције од сажаљења над судбином сиромаха - њен циљ је да изазове страх код младог читаоца и подстакне одговорност за овоземаљске поступке.

Последњу групу умирућих субјеката у Сундечићевој збирци чине они који су означени релационо, као чланови породице (мајка, отац, син; преци), при чему они у његовој поезији остају неименовани. Кад се о њима говори, узроци смрти могу да буду различити - у једној песми је то старост, у другој борба за отаџбину; емоције које прате ту смрт умногоме су везани за квалитет односа према умрлом. Синови који траже богатство показаће недостатак емоција у вези са смрћу свог оца ${ }^{24}$; лирско ја које је везано за мајку пред сликом њене могуће смрти осетиће тугу, док у емоцијама које прате живот дат за отаџбину предњачи понос. Занимљиво је да се у овим песмама неколики простори шире у репрезентацији смрти у односу на горе наведене. Најпре,

кад предзмајевска поезија постоји. В. В. Вукомановић Растегорац, Лексика као огледало времена у контексту предзмајевске поезије за деиу, „Детињство” 2017, бр. 1, с. 74-75.

${ }^{20}$ Ibidem, c. 61.

${ }^{21}$ Ibidem, c. 82.

22 B. L. V. Toma, Antropologija smrti I, prev. Z. Stojanović i M. Radović, Beograd 1980, c. 28.

23 І. Сундечићъ, Низ драгоиъног..., с. 80-81.

24 Ваља приметити: слика у којој отац на самртничкој постељи дозива синове да се са њима опрости и каже им последњи савет у значајној мери подсећа на укроћену см рт како је описује Филип Аријес. В. F. Arijes, Eseji o istoriji smrti..., с. 28. 
ваља поменути да се у песми Мати по први пут о смрти проговорило из перспективе сина (не нужно и детета, јер овај глас може бити и глас мушкарца у зрелом добу), да се појављује брига за смрт другог која је интензивнија од бриге за сопствену, као и то да се из перспективе сина антиципирају сопствене предсмртне речи и смрт. Начини загробног трајања добијају алтернативу, а тиме и осмишљење смрти: осим рајске егзистенције, појављује се симболичко трајање кроз тестамент који се оставља свом потомству. Такође, у стиховима песника који је, по речима Марка Цара, сав свој књижевни рад проткао патриотизмом и грађанском врлином ${ }^{25}$ морало се јавити и загробно трајање кроз извојевану слободу отаџбине. Та се слобода, дакако, остварује кроз борбу која шири простор умирања, па није то више само гробље, већ и бојно поље. Неучествовање у борби доноси земаљску и небеску казну: кости издајице отаџбинској земљи „Не б’ аманетъ могле бытъ: / Нег’ ка’ знацы грдне злости, / Морале бы врхъ нъ плитъ”26, а он би издајом „самъ себи зажегао / Въчне клетве живый стинь"27.

Кад је реч о језичком обликовању, ваља рећи да је у говору о смрти повремено присутна деминуција, која је карактеристична за српске романтичаре, али се овде може читати и као покушај да се појмови везани за њу донекле припитоме: смрт се именује као „последњи часак”28, а преминули сиромах као „мртви сиромашак”29; епитети гроб описују као таман ${ }^{30}$; у метафорично-алегоријском кључу смрт се види као гашење свеће живота $^{31}$, жетва ${ }^{32}$, која поравнава умрле ${ }^{33}$, која их, иако деперсонализована, бере $^{34}$, а уме да буде и љута ${ }^{35}$; смрт, коначно, подиже са земље ${ }^{36}$. Очевидно је из горе наведених примера да се контраст такође често упошљава у репрезентацијама смрти, најчешће из моралистичких разлога.

Сундечић је поставио основу певања о смрти за децу, а оно ће бити обогаћено већ две године касније, са појавом књиге Сдъ и медъ (1858) српског учитеља Ђорђа Рајковића (1825-1885). Рајковић ју је дефинисао као

${ }^{25}$ М. Цар, Јован Сундечић (критичко-биографска студија), [у:] Јован Сундечић свештеник, пјесник, дипломата, прир. Д. Певуља, Бања Лука 2009, с. 95.

${ }^{26}$ І. Сундечићъ, Низ драгоиъног..., с. 56. Приврженост „родној груди” Луј Венсан Тома региструје као једну од универзалија кад је питање људско опхођење према смрти, а укидање могућности да се буде сахрањен у њој је укидање сусрета са мајчинским загрљајем који она умрлом може да пружи. L. V. Toma, Antropologija smrti..., c. 28; Moren, Čovek i smrt..., c. 138.

27 І. Сундечићъ, Низ драгоиъног..., с. 55.

${ }^{28}$ Ibidem, c. 45.

29 Ibidem, c. 61.

${ }^{30}$ Ibidem.

31 Ibidem, c. 45.

32 Ibidem, c. 28.

33 Ibidem, c. 54.

${ }^{34}$ Ibidem, c. 58.

${ }^{35}$ Ibidem.

${ }^{36}$ Ibidem, c. 45. 
збирку шаљиво-поучних чланака и она се састоји из два дела: „производа у стиховима” и „производа у прози”; предмет наше анализе биће њен први, стиховани део.

Рајковићев говор о смрти не наликује много Сундечићевом; оно што је потоњи увео у певање о смрти код песника Једа и меда или је присутно у мањој мери, па и то уз одступања и друкчије нагласке, или није присутно уопште.

Рајковић ће, попут Сундечића у појединим песмама проговорити о универзалности смрти и тај ће говор носити моралистички тон. Ипак, он ће тек на једном месту директно упућивати на православну традицију. Наиме, само у песми Правданг Божієгъ провићеня поради злоће у свету читамо о Богу који, по речима лирског ја, праведно суди о људском срцу, као и о томе да „Усевъ негда судомъ Божіимъ, / Постати ће жетвомъ славномъ” 37. У осталим песмама овог типа тек се имплицитно може ишчитавати загробна егзистенција (онда кад се, рецимо, каже да је овај свет само „пута нашегъ преноћиште"38); експлицитнији је страх пред крхкошћу живота, чак и онда кад се о њему проговара алегоријски као о пловидби бродом којем пропаст непрекидно прети ${ }^{39}$.

Слично као код Сундечића, у Једу и меду налазимо зачетке патриотског обликовања смрти. Ако је први о томе певао у Домовини, други доноси песму Србскомъ роду на ново лето. И овде ће, као и код Сундечића, бити акцентована трошност тела („Трошный тела нашегъ дробъ” ${ }^{\circ}$ ), а у исто време бити указано на начин како се смрт може трансцендирати: кроз потомке. Занимљиво је да у Рајковићевој интерпретацији потомство даје свој суд у вези с оним што му је остављено у наследство. Могло би се рећи да је Божји суд у овој песми код Рајковића доживео трансформацију и конкретизацију у људски суд наследника.

Када говори о смрти родитеља и драгих људи, Рајковић у својој поезији за децу и младеж снажније наглашава емпатијски аспект говора о умирању, те у први план поставља тугу за преминулима (На майчиномъ гробу, Утъха). Она може и не мора бити лексички експлицирана, али је свакако појачана одабиром одређене перспективе и екскламативношћу израза. У првонаведеној песми лирско ја се обраћа преминулој мајци, док се у другој из свеобухватног $m u$ полако прелази у инклузивно $м u^{41}$. Стихови „Утехе” наглашавају интензитет психичког доживљаја туговања за умрлим, али у исто време, као што се види, казују да се са том тугом мора живети, те да и она има своје

37 Ђ. Райковићъ, Сдъ и медъ, У Новомъ Саду 1858, с. 15.

38 Ibidem, c. 30.

39 Ibidem, c. 31.

${ }^{40}$ Ibidem, c. 5.

41 Уп.: „Сунцемъ, веруй, начинънимъ / Изъ сувога чистогъ злата, / У данъ не ћешъ ноћь претворит' / Црну ка'но пакла врата. [...] Ал' ноћь вечно не мож' траят', / Засійнуће зора млада, / Па излечит' грдне ране, / Коє смрть намъ драгихъ зада"”. Ibidem, с. 32. 
окончање; тако је у овој песми по први пут смрт асимилована и отворен пут могућности стишања бола и његовом заборављању. Потресност смрти само је у једном случају оставила простор за приказ умрлог тела - поменута је, наиме, „ладна груд” мајке у песми На майчиномъ гробу, а трагичност смрти je, чини се, тражила да буде ублажена говором о загробном трајању, које у одређеном смислу даје смрти сврху. Тако ће у песми која тематизује мајчину смрт лирско ја прихватити постојање небеског обитавалишта у које се сели душа преминуле; то је обитавалиште место у којем мајчина „душа [...] чиста, / Вечный себи избра дворь "42, а који је испуњен хором серафима. Уз ове две песме, ваља поменути песму Родительи у гробу, у којој је моралистички тон превладао емпатијски. Песма која је испевана као обраћање ономе који је остао (или може да остане) без родитеља, опомиње и на то како потомци могу негативно да утичу на живот умрлих ${ }^{43}$

Специфичност Рајковићевих песама долази до изражаја највише у стиховима у којим се умирући субјект конкретизује преко одређеног занимања (адвокат, кнез, минералог, судија) или одређене особине (ждеравац, тврдица). То проширење спектра умирућих повући ће за собом мноштво поступака који се код Сундечића нису могли наћи. Најпре, отвориће простор за (црно)хуморно и донекле сатирично обликовање песничког проседеа ${ }^{44}$. Најпре је ту прозирно именовање појединих ликова, које је у уској вези са особинама које се критикују: адвокат је Оштроноктић, кнез је Љутица, ждеравац ће носити име Гојко (уп. глагол гојити се). Хуморна интенција ће омогућити и то да се међу узроцима смрти нађе жеља „мудре” тврдице да утекне од плаћања дажбина ${ }^{45}$, а да се међу емоцијама које смрт прате нађе, примерице, притворна туга народа ${ }^{46}$ или чак и нешто што би се могло окарактерисати као злурадост ${ }^{47}$. Ако је загробно трајање негде експлицирано, у њему се само хиперболичније показује карактер умрлог пре његове смрти. Тако ждеравац и у гробу вари јело које је за живота обедовао ${ }^{48}$, лирско ја се, тобож, моли да Бог не суди кнезу Љутици као што је он судио својим сељанима

42 Ibidem, c. 6 .

43 Уп.: „Ако л’ пођешъ путемъ злоће, / Веруй тврдо твоє оће / Родитель и у раки / Проклиняти човекъ свакій”. Ibidem, с. 33.

44 Њега је је песник најавио читатељима у своме предговору: „Да не бы мои читательи дремали, да ій не бы ти педагогички чланци озбильношћу своіомъ уморили, удешено є тако, да крозъ цело веє духъ отреснієгъ говора, духъ сатире и хумора". Ibidem, c. IX.

45 Уп.: „Ћирь Яня є подъ земльицу лег'о, [...] / Да не дає ништ' на ново лето”. Ibidem, c. 35 .

46 Уп.: „Цела варошь у плачь бризну / Што - већъ давно умро ниє”. Ibidem, с. 36.

47 Уп.: „Живъ тумар'о с' за каменьмъ / Колико те ноге носе; / Каменъ овде дадоше ти, / Те си єдномъ смиріо се". Ibidem, с. 37.

48 Може бити да је у позадини оваквог обликоввања веровање присутно у српском народу „да и тело, у некој форми, после смрти продужује живот, сличан животу на овоме свету, са истим жељама и потребама”. В. за то: В. Чајкановић, Мит и религија у Срба, Београд 1973, с. 85 . 
(N.B.: и у овом, хумористичком контексту опстаје идеја Божјег суда), а за адвоката је сигурно да је душу „предао у руке божје”, али у исто време није сигурно и да ће Бог његову руку примити итд. У том маниру ваља разумети храбар и несвакидашњи олфактивни приказ умрлог тела, који се контрастира претераној бризи за угодним мирисом у овом животу - тај приказ налазимо у дистиху Надплочно некомъ (кои се за живота яко мирисомъ мазао) ${ }^{49}$. Као што користи хиперболу и дезаутоматизацију фразеологизма да изазове осмех читаоца, Рајковић тако воли да употреби овештале патетичне изразе и да поентира бритком иронијом ${ }^{50}$. Битно је, ипак, приметити да упошљавање овакве представе смрти у стиховима и употреба хумора ни у којем смислу нису одвојени од утицаја на морално обликовање реципијента.

Могло се приметити да поједине песме носе одређење надгробје или натплочно; такође, има оних које у наслову садрже реч надгробница. Све оне сугеришу да је у појединим песмама искоришћена форма стихованог епитафског записа. Она је понегде сугерисана насловом, ретко уводном формулом „овде лежи” 51 , чешће то дочарава ,једносмерна комуникација, намењена искључиво обраћању покојнику: он је увек «ти»" 52 , а песник понекад уводи и „специфичну тековину наше епитафске традиције: покојникаговорника, покојника «активног» учесника загробне комуникације, који се обраћа живима" ${ }^{33}$. Та форма онда бива садржајем „изневерена” и отуда, такође, хуморни ефекат. Ако епитафско вредновање покојника обично „мање иде за тим да га индивидуализује а више тежи да га подведе под један општи идеал ни лик" ${ }^{24}$ [истакао В. В. Р.], Рајковић своје преминуле субјекте не идеализује нимало; од епитафа се тражи и то да „говори не само «бираним» него и «дирљивим» речима" 55 - у овим епитафима, међутим, нема ни патетике којом се дочарава тескоба опстанка ожалошћених нити жеље да се загробни живот преминулог у таквом тону вербализује ${ }^{56}$. Рајковићеви епитафи који наизглед узимају на себе задатак да заједницу обавесте о томе какав је покојник био и како је умро, и у којима је тужбалички тон сасвим потиснут и неразвијен, постају тако нека врста сатиричног летописа имагинарне вароши ${ }^{57}$.

49 Уп.: „Ко л’ је лего овде вечни санак спати - / Можеш омирисат', не треба читати.” Ibidem, c. 37.

50 „Умрла си, нъжномъ рукомъ / Два ти склопихъ ока твоя: / Ты у земльи, я у кући / Нашао самь садъ покоя." Ibidem, с. 38.

51 Ibidem, c. 36,

52 I. Čolović, Divlja književnost: etnolingvističko proučavanje paraliterature, Beograd 2000 , c. 44.

53 Ibidem, c. 36.

54 Ibidem, c. 91.

55 Ibidem, c. 103.

${ }^{56}$ Ibidem, c. 92-94.

${ }^{57}$ Up.: ibidem, c. 34. 
Када се баци поглед на најконкретнији језички ниво, гроб задобија уобичајене епитете - он је црн ${ }^{58}$ и хладан ${ }^{59}$. Смрт је, међутим, виђена као нешто што задаје ране онима који су ожалошћени ${ }^{60}$, нешто што граби 61 , али је у појединим случајевима припитомљена деминуцијом као вечни санак ${ }^{62}$, пруд мира ${ }^{63}$ или се у обрисима образује слика анђела смрти који узима душу и носи на небо 64 , док је све пре смрти виђено као усев што доноси род судом Божјим који се поистовећује са жетвом ${ }^{65}$. А у основи стилистичког обликовања - то се могло већ горе видети - стоје апострофа и хипербола, а потом дезаутоматизација фразеологизма и иронија.

Кад се анализе сведу, може се закључити да се смрт у Сундечићевим и Рајковићевим стиховима претежно тематизује у моралистичком, а знатно мање у емпатијском маниру. Моралистички поглед на њу код Сундечића је умногоме дефинисан хришћанским оквирима, што се донекле може видети и као последица историјског тренутка у којем су ове песме настале: у доба романтизма и националног освешћења православна вера је играла велику улогу у конституисању националног идентитета, па и у васпитању омладине. Певање о смрти код овог песника у начелу подразумева говор о смрти религијски битних фигура (Христа, Светог Саве), тематизовање Христове жртве и васкрсења, који људском роду доносе радост победе над смрћу. У збирци Низ драгоцђног бисера присутан је у том кључу и говор о Божјем (праведном, страшном) суду, те загробном трајању у рају или паклу. Такав поредак ствари учиниће да начин живљења и његов смисао буду у највећој мери одређени смрћу - овоземаљска егзистенција постаје тек средство да душа задобије пребивалиште у вечности. Не би ли учинио поруку упечатљивијом, овај песник експлицитно даје и приказ декомпозиције умрлих тела богаташа и сиромаха, при чему контраст између њих треба на још један начин да посведочи последице (не)исправног живљења. Визија загробне егзистенције у рају допуњена је кроз став да се после смрти

58 Ibidem, c. 5 .

59 Ibidem, c. 11.

${ }^{60}$ Ibidem, c. 32.

${ }^{61}$ Ibidem, c. 36.

62 Ibidem, c. 37. Метафора сна, познато је, представља једну од најдубље укорењених метафора за смрт, који се види као „исконски сан”. Више о томе: E. Moren, Čovek i smrt..., c. 142 и даље. Такође, у књизи Б. Таурека читамо да се у хришћанској антици „смрт још увек приказује без црта ужаса као сан који спушта бакљу”. Б. Х. Ф. Таурек, Филозофирати: учити умирати?, прев. Д. Смиљанић, Нови Сад 2009, с. 90.

63 Ibidem, c. 7. Ова се слика може препознати као реликт старог веровања да се „други свет налази на неком острву, на које понекад иду само изабрани, одлични људи, понекад уопште сви покојници”. Уп.: В. Чајкановић, Мит и религија у Срба, Београд 1973, с. 81. Као што се види из даљег текста, оно у Рајковићевој поезији опстаје заједно са веровањем да душа путује на небо.

${ }^{64}$ Ibidem, c. 3.

65 Ibidem, c. 15. 
траје кроз потомке и добра дела која се за њих чине, а тај се став упошљава у патриотском кључу борбе за ослобођење домовине.

У моралистичким песмама о смрти Ђорђе Рајковић се доста разликује од свог савременика. Он за умируће фигуре претежно бира типске ликове и у његовим стиховима је доминантан сатирични хумор. Хумористичко обликовање утиче онда и на тематизацију узрока смрти и осећања која је прате; хумор омогућава повремено и опис умрлог тела, а у крајњој инстанци утиче и на представу загробног трајања, које ће бити углавном хиперболично наличје овоземаљског живота. Особеност Рајковићевих претежно кратких песама биће употреба епитафске форме у хумористичко-моралистичком кључу. Рајковић, у односу на Сундечића, посвећује више пажње емпатијском говору о смрти. Простор емпатијског певања о умирању у Сундечићевој збирци тек је начет песмом Мати, док Рајковић у овом маниру пише неколико песама. Овај тип говора о смрти присутан је кад је реч о смрти најближих (најчешће мајке), доминантне емоције су туга и бол за преминулим, а по правилу се та осећања примирују тако што се приказ умрлог тела заобилази и што се исказује вера да се душа драге особе преселила у боље и трајније, рајско обитавалиште.

Ако се приказ смрти осмотри са језичко-стилског становишта, уочава се то да ови песници гроб описују устаљеним епитетима (таман, хладан, црн); смрт углавном задобија негативне или неутралне епитете, у којима је неупитна њена моћ над човеком: она је љута, задаје ране, бере и граби; с друге стране, она поравнава и представља тренутак жетве који показује какав је плод донело човеково живљење на земљи. У појединим песмама смрт се пак припитомљава употребом деминуције, а признаје се и могућност да њен долазак није толико лош по умирућег: она подиже са земље (већ у том изразу присутна је нада у трајање на небу, у рају), или одводи на мира пруд; њено припитомљење присутно је, коначно, и у понешто оксиморонском именовању фигуре анђела смрти, будући да се анђео у хришћанским оквирима најчешће види као чувар и избавитељ, те да је обично оличење узвишене доброте.

На крају, може се рећи да су поменута два песника поставила основе у певању о смрти намењеном деци. Из упоређења начина на који су је тематизовали, очевидно је, међутим, да се једном постављена основа даље развијала и обогаћивала - на који начин је даље текло њено (пре)обликовање и шта је на њу утицало важан је задатак будућих истраживања за које смо овде покушали да дамо релевантно полазиште.

\section{Библиографија}

Altiser L., Ideologija i državni ideološki aparati, prev. A. Filipović, Loznica 2009.

Antologija srpske poezije za decu predzmajevskog perioda, prir. Z. Opačić, <http://www.antologijasrpskeknjizevnosti.rs/ASK_SR_AzbucnikDela.aspx> [pristupljeno: 1.08.2017].

Antologija srpske poezije za decu, prir. D. Radović, Beograd 1984. 
Arijes F., Eseji o istoriji smrti na Zapadu, prev. Z. Banjac, Beograd 1989.

Car M., Jovan Sundečić (kritičko-biografska studija), [u:] Jovan Sundečić - sveštenik, pjesnik, diplomata, prir. D. Pevulja, Banja Luka 2009.

Čajkanović V., Mit i religija u Srba, Beograd 1973.

Čolović I., Divlja književnost: etnolingvističko proučavanje paraliterature, Beograd 2000.

Dečja poezija srpska, prir. B. Ćosić, Novi Sad - Beograd 1965.

Ellis J. B., Stump J. E., Parents'Perceptions of Their Children's Death Concept, „Death Studies” XXIV, 2000.

Gajić D., Književno delo Petra Despotovića, „Dometi” LI, 1987.

Gutiérrez I. T., Miller P. J., Rosengren K. S., Schein S. S., Affective Dimensions of Death: Childrens Books, Questions, and Understandings, „Monographs of the Society for Research in Child Development" 2014.

Jeknić D., Srpska književnost za decu 1: istorijski pregled, Beograd 1998.

Marković S. Ž., Zapisi o književnosti za decu, Beograd 1973.

Moren E., Ćovek i smrt, prev. B. Jelić, Beograd 1981.

Raйkovićъ Đ., Cdъ i medъ, U Novomъ Sadu 1858.

Speece M. W., Brent S. B., Children's Understanding of Death: A Review of Three Components of a Death Concept, „Child Development” 1984.

Sundečićъ I., Niz dragocronog bisera, U Zadru 1856.

Taurek B. H. F., Filozofirati: učiti umirati?, prev. D. Smiljanić, Novi Sad 2009.

Talwar V., Talking to Children about Death in Educational Settings, [in:] Children's Understanding of Death, prir. V. Talwar et al., Cambridge 2011.

Toma L. V., Antropologija smrti I, prev. Z. Stojanović i M. Radović, Beograd 1980.

Vukomanović Rastegorac V., Leksika kao ogledalo vremena u kontekstu predzmajevske poezije za decu, „Detinjstvo” 2017.

Vuković N., Uvod u književnost za djecu i omladinu, Podgorica 1996.

\section{The forming of the discourse about death in Serbian poetry for children and young adults during its inception}

\section{Summary}

Representations of death in Serbian poetry for children and young adults have not been researched systematically to this day. The goal of this paper, therefore, is to point out the initial positions taken up during the forming of these representations, through the analysis of verses by Jovan Sundečić and by Đorđe Rajković. In brief, both poets view death as something that has power over man, the main difference being that Sundečic constructs the theme of death within a Christian framework without using humor, while Rajković abandons the framework of Christianity and assigns a significant role to humor in his writing about death.

Keywords: representations of death, Serbian poetry for children and young adults, Jovan Sundečić, Đorđe Rajković, 19th century 


\section{Репрезентация высказываний о смерти в первых сербских поэтических произведениях для детей и подростков}

\section{Резюме}

Представления о смерти в сербской поэзии для детей и подростков до сих пор подробно не исследовались. В связи с этим цель настоящей работы - систематизировать исходные проявления этих идей в стихотворениях Иоанна Сундечича и Джордже Райковича. У обоих поэтов смерть показана одинаково: как нечто, имеющее власть над человеком. При этом, однако, Сундечич оформляет высказывания о смерти согласно христианскому пониманию и без тени юмора, а Райкович, обращаясь к этой теме, выходит за рамки христианства и уделяет значительное место юмору.

Ключевые слова: представления о смерти, сербская поэзия для детей и подростков, Иоанн Сундечич, Джордже Райкович, XIX столетие 